\title{
Comparison between the bacterial and oligosaccharide content of ileostomy effluent in subjects taking diets rich in refined or unrefined carbohydrate
}

\author{
L BERGHOUSE, S HORI, M HILL, M HUDSON, J E LENNARD-JONES, \\ AND E ROGERS
} From St Mark's Hospital, London, and the Bacterial Metabolism Research Laboratory, PHLS-CAMR,
Porton Down, Salisbury

SUmmary Dietary surveys have shown that patients with Crohn's disease tend to eat more sucrose than control subjects and this investigation was undertaken to determine whether a diet rich in refined carbohydrate affects the bacterial flora of the terminal ileum. Ileostomy effluent in five patients with Crohn's disease and five with ulcerative colitis after two weeks on a diet rich in sucrose and refined cereal has been compared with the same period on a diet low in sucrose and rich in unrefined cereal. Observations were made hourly for nine hours after equicaloric breakfasts representing the two diets. The amount of ileostomy effluent was greater on the unrefined carbohydrate diet both in terms of wet weight $(238 \pm 89 \mathrm{~g} v s 162 \pm 79 \mathrm{~g}, \mathrm{p}<0.02)$ and dry weight $(23.6 \pm 6.8 \mathrm{~g}$ vs $14.9 \pm 6.6 \mathrm{~g}, \mathrm{p}<0.01)$; surprisingly, the amount of glucose and oligosaccharide was also greater $(169 \pm 41 \mathrm{mg} v s 82 \pm 26 \mathrm{mg}, \mathrm{p}<0.001)$ in all 10 volunteers. The bacteriological flora per gram was also higher on the unrefined carbohydrate diet after the test meal ( $p<0.02$ between three and six hours) as a result of a general increase in all organisms. The relative proportions of the organisms did not vary between the two diets. No differences were detected between patients with ulcerative colitis and those with Crohn's disease.

Dietary surveys have shown that patients with Crohn's disease tend to eat more sucrose than do control subjects. ${ }^{1-9} \mathrm{~A}$ diet rich in refined carbohydrate is characteristic of northern Europe, an area where the incidence of Crohn's disease has increased markedly in the last 50 years. It seems possible that such a diet affects the bacterial flora of the terminal ileum and right colon, the commonest site of Crohn's disease. We have therefore studied the ileostomy effluent in 10 healthy subjects who volunteered to take two diets, one rich in refined carbohydrate and the other rich in unrefined carbohydrate, each for a period of two weeks. This paper reports that the bacterial flora differed at the end of the test periods, the diet rich in unrefined carbohydrate favoured the development of more profuse flora, perhaps associated with the finding that the

Address for correspondence: Professor J E Lennard-Jones, St Mark's Hospital, City Road, London EC1V 2PS.

Received for publication 16 December 1983 quantity of oligosaccharides in the effluent was greater with this diet.

\section{Methods}

\section{SUBJECTS}

The study was carried out on 10 ileostomists. Colectomy had been performed at least nine months previously for colonic Crohn's disease in five (in one patient $50 \mathrm{~cm}$ of terminal ileum had also been removed) and for ulcerative colitis in the other five. In each group there were three men and two women. The average age was 44 years (range 22-68 years) in the Crohn's disease group and 50 years (range 32-70 years) in the ulcerative colitis group. No patient with Crohn's disease had evidence of small bowel recurrence, although radiology was not performed for this study. Three patients had had perianal or perineal disease since surgery and in two this was present at the time of the study. No patient was taking anti-inflammatory drugs or had taken an 
antibacterial drug during the weeks preceding the study, no antidiarrhoeal agents were consumed during the study period.

DIET

Each subject took in random order for two weeks, with a rest period of at least one week between, a diet similar to an average Western diet which contained much refined cereal food and sucrose with little unrefined cereal (diet A) and a diet which aimed to minimise refined cereal and sucrose with the substitution of unrefined cereal foods (diet B). The subjects were advised about the two diets by a dietician and given a booklet of instructions. The principles of the diets are shown in Table 1.

DIETARY ASSESSMENT

During each two week period the subject kept a record of foods eaten on one day and at the end a dietician made a quantitative assessment of the cereals and sugar taken on that day using the tables of Paul and Southgate. ${ }^{10}$

MEALS ON STUDY DAY

On the 15th day, after keeping to one of the diets for the previous two weeks, the subject came to the hospital after an overnight fast. A test breakfast of composition corresponding to the diet period was given. The two test breakfasts at the end of each diet period were calculated to be equicaloric, contain

Table 1 Composition of the two diets tested

\begin{tabular}{ll}
\hline $\begin{array}{l}\text { Foods allowed freely in diet } A \\
\text { and to be avoided in diet } B\end{array}$ & $\begin{array}{l}\text { Foods allowed freely in diet } B \\
\text { and to be avoided in diet } A\end{array}$ \\
\hline $\begin{array}{l}\text { White or refined (other than } \\
100 \% \text { extraction) flour in } \\
\text { bread, cakes, biscuits, pastries, } \\
\text { spaghetti, macaroni, semolina } \\
\text { or pasta. }\end{array}$ & $\begin{array}{l}\text { Wholemeal bread (100\% } \\
\text { extraction), Ryvita, Ryking, } \\
\text { Macvita, oatcakes, porridge } \\
\text { oats, Shredded Wheat, Puffed } \\
\text { Wheat, Weetabix, } \\
\text { Weetaflakes, Malted } \\
\text { Shreddies, home made muesli } \\
\text { without sugar. Bran, Hi-bran } \\
\text { or cereals containing bran. }\end{array}$ \\
$\begin{array}{l}\text { Energen rolls or starch-reduced } \\
\text { bread. }\end{array}$ & $\begin{array}{l}\text { Brown unpolished rice. } \\
\text { Wholemeal macaroni or pasta. }\end{array}$ \\
$\begin{array}{l}\text { Breakfast cereals other than } \\
\text { those listed opposite. }\end{array}$ & Unsweetened fruit. \\
$\begin{array}{l}\text { White or ground rice. Tapioca, } \\
\text { sago, arrowroot, cornflour, } \\
\text { custard, blancmange, ice } \\
\text { cream, instant pudding mixes. }\end{array}$ & $\begin{array}{l}\text { Unsweetened beverages and } \\
\text { drinks. }\end{array}$ \\
$\begin{array}{l}\text { Sugar, sweets, confectionary, } \\
\text { sweetened preserves. }\end{array}$ & \\
$\begin{array}{l}\text { Sweetened beverages and } \\
\text { drinks. }\end{array}$ & \\
\hline
\end{tabular}

Common to both diets: vegetables, milk and milk products, meat, fish, eggs, fats and oils.
Table 2 Calculated composition of the two test breakfasts taken before the collections of the ileostomy effluent

\begin{tabular}{lcc}
\hline & Breakfast $A$ & Breakfast B \\
\hline Energy (Kcal) & 445.0 & 430.0 \\
Simple sugars (g) & 13.5 & 3.5 \\
Starch (g) & 45.0 & 47.0 \\
Fibre (g) & 2.5 & 9.5 \\
Protein (g) & 13.0 & 14.0 \\
Fat (g) & 15.5 & 16.5 \\
\hline
\end{tabular}

equal amounts of protein and fat, but to differ in their relative contents of sucrose and dietary fibre (Table 2).

The foods consisted of white bread and butter, Rice Krispies, milk, sugar, and tea in one; wholemeal bread and butter, Weetabix, milk and tea in the other.

Four hours later one of two lunches was given which were again equicaloric and differed similarly in the ratio of simple sugars to dietary fibre. A coloured marker was given to some patients with this meal and ileostomy effluent was collected after breakfast until this marker appeared at eight to nine hours or for the same period in those not given a marker.

\section{COLLECTIONS FOR CHEMICAL ANALYSIS ON STUDY} DAY

The total output of ileostomy fluid for each hour was collected into a container and cooled with solid carbon dioxide. At the end of each hour the effluent was stored at $-25^{\circ} \mathrm{C}$ until analysis.

\section{COLLECTIONS FOR BACTERIAL ANALYSIS}

In an effort to maintain anaerobic conditions a Foley catheter was inserted approximately $10 \mathrm{~cm}$ into the ileostomy before the test breakfast and at the end of each hour after breakfast until the marker appeared and a sample of ileal contents was collected by gentle suction into a syringe. Approximately $0.5 \mathrm{~g}$ of this sample was immediately placed into a preweighed bottle of cryoprotective glycerol broth ${ }^{11}$ frozen on solid $\mathrm{CO}_{2}$ and maintained at $-25^{\circ} \mathrm{C}$ until analysis. The exact amount of ileostomy fluid was determined from the increase in weight of the bottle and contents.

QUANTITATIVE BACTERIOLOGICAL ANALYSIS The samples were thawed rapidly at $37^{\circ} \mathrm{C}$ within a flexible anaerobic chamber, ${ }^{12}$ homogenised using a vortex mixer, and $25 \mu$ l aliquots of a decimal dilution series (prepared in prereduced broth) were pipetted on to the surface of a range of solid media using a modification of the method of Miles and Mistra. ${ }^{13}$ The non-selective and selective media used 
were similar to those described by Borriello et $a^{14}$ with the exception that all media were supplemented with $1 \%$ neutralised liver digest (Oxoid L27) and vitamin $\mathrm{K}_{1}(1 \mathrm{mg} / \mathrm{l})$ substituted for menadione. The medium used for the isolation of veillonellae was that of $\operatorname{Rogosa}^{15}$ but with vancomycin $(7.5 \mathrm{mg} / \mathrm{l})$ replacing the streptomycin. Rifampicin agar ${ }^{16}$ was prepared by adding $50 \mathrm{mg} / \mathrm{l}$ rifampicin (as a solution in $50 \%$ dimethyl sulphoxide) to supplemented brain-heart infusionblood agar. Enterococci were sought on gentamicinthallous acetate-carbonate medium. ${ }^{17}$ Oral streptococci were enumerated on Mitis-Salivarius agar (Difco) and yeasts on Saboraud's medium with $40 \mathrm{mg} / \mathrm{l}$ chloramphenicol succinate added. Clostridial spores were selected by treatment of the dilution series with ethanol (final concentration $50 \%$ ) for one hour at room temperature. ${ }^{18}$ Anaerobic media were incubated at $36^{\circ} \mathrm{C}$ for three to five days under an atmosphere of $20 \% \mathrm{CO}_{2}$ in $\mathrm{H}_{2}$. Lactobacillus agar and Mitis-Salivarius agar were incubated in $20 \% \mathrm{CO}_{2}$ in air for two days. Aerobic plates were examined after 18 hours and 48 hours incubation. Colonies at appropriate dilutions were counted and subcultured. Isolates were identified by their growth in particular media, aerotolerance, gram morphology, biochemical characteristics and fermentation end-products. ${ }^{12} 1419$

CHEMICAL ANALYSIS

Wet and dry weight were assayed by weighing before and after lyophilisation. The samples of ileostomy fluid were first deproteinised by Carrez reagents; zinc acetate in acetic acid and then aqueous potassium ferrocyanide $;^{20}$ both of these reagents give flocculent precipitates (to which the protein adsorbs) which are removed by centrifugation together with the solid particulate matter, such as dietary fibre, bacteria etc, present in the samples. Analysis was carried out on the clear supernatant, which appeared to contain no starch (as determined by the starch-iodine reaction). Presumably the starch was either in the particulate material or, possibly, was coprecipitated with the protein. The material analysed therefore contained monosaccharide, disaccharide, and the smaller molecular weight polysaccharides - the oligosaccharides, which contain 2-10 monosaccharide units. ${ }^{21}$ The amount of glucose in the samples was assayed using glucose oxidase and oligosaccharides in the sample were assayed as glucose after hydrolysis with $2 \mathrm{~N}$ sulphuric acid.

BREATH HYDROGEN ANALYSIS

Two breath samples of alveolar air were taken at each hour by a modified Haldane-Priestly tube and assayed for hydrogen by gas chromatography. ${ }^{22}$

STATISTICAL ANALYSIS

Mean values were compared by Student's paired $t$ test.

\section{Results}

DIETARY ASSESSMENT (Table 3 )

A dietary assessment was possible in seven of the 10 subjects; in one other subject the records were difficult to interpret and the remaining two subjects did not keep records. The results in Table 3 show that compliance with the dietary advice was good, although one of the subjects did not eat any refined sugar even during diet $\mathrm{A}$.

BIOCHEMISTRY (Table 4)

The mean total wet and dry weight of ileostomy effluent was significantly higher on diet B than on diet $A$. In all 10 subjects there was an increased volume of effluent in the first sample after breakfast and again at five hours (the first sample after lunch). At these times the ratio of fluid to solid matter was greater than at other times.

Although the total glucose and oligosaccharide was less than $250 \mathrm{mg}$ for the nine hour study period in all 10 patients on either diet, the small amounts present in ileostomy effluent were always higher on $\operatorname{diet} \mathrm{B}$ than on $\operatorname{diet} \mathrm{A}$, despite the fact that the intake of sucrose and starch was very much lower on diet B than on diet A. Similarly the concentration of glucose and small oligosaccharides in all but one of

Table 3 Analysis of foods eaten on a representative day during the preliminary run up period on the diet low in unrefined carbohydrates (diet $A$ ) and high in unrefined carbohydrate (diet B). No analysis was possible on three subjects

\begin{tabular}{|c|c|c|c|c|c|}
\hline Disease & Patient & Diet & $\begin{array}{l}\text { Fibre } \\
(\mathrm{g})\end{array}$ & $\begin{array}{l}\text { Sucrose } \\
(\mathrm{g})\end{array}$ & $\begin{array}{l}\text { Starch } \\
\text { dextrins } \\
(\mathrm{g})\end{array}$ \\
\hline \multirow{6}{*}{$\begin{array}{l}\text { Crohn's } \\
\text { disease }\end{array}$} & \multirow[t]{2}{*}{2} & A & $15 \cdot 5$ & $47 \cdot 5$ & $164 \cdot 0$ \\
\hline & & B & $23 \cdot 5$ & $15 \cdot 0$ & $110 \cdot 5$ \\
\hline & \multirow[t]{2}{*}{3} & A & $9 \cdot 0$ & $40 \cdot 0$ & $105 \cdot 0$ \\
\hline & & B & $13 \cdot 0$ & 0 & $90 \cdot 0$ \\
\hline & \multirow[t]{2}{*}{6} & A & $9 \cdot 5$ & $92 \cdot 5$ & $185 \cdot 0$ \\
\hline & & B & $29 \cdot 0$ & $5 \cdot 0$ & 155.0 \\
\hline \multirow{8}{*}{$\begin{array}{l}\text { Ulcerative } \\
\text { colitis }\end{array}$} & \multirow[t]{2}{*}{7} & A & $19 \cdot 5$ & $115 \cdot 0$ & $215 \cdot 0$ \\
\hline & & B & $28 \cdot 5$ & $10 \cdot 0$ & 115.0 \\
\hline & \multirow[t]{2}{*}{8} & A & $10 \cdot 0$ & $82 \cdot 5$ & 145.0 \\
\hline & & B & $21 \cdot 5$ & $10 \cdot 0$ & $100 \cdot 5$ \\
\hline & \multirow[t]{2}{*}{9} & A & $19 \cdot 5$ & $117 \cdot 0$ & $165 \cdot 5$ \\
\hline & & B & $29 \cdot 0$ & trace & $80 \cdot 0$ \\
\hline & \multirow[t]{2}{*}{10} & A & $8 \cdot 5$ & 0 . & $90 \cdot 0$ \\
\hline & & B & $12 \cdot 0$ & 0 & $50 \cdot 5$ \\
\hline
\end{tabular}


Table 4 Physical and chemical characteristics of the ileostomy effluent collected during the whole study period after the two test breakfasts

\begin{tabular}{|c|c|c|c|c|c|}
\hline Patient & Diet & $\begin{array}{l}\text { Total wet weight } \\
\text { excreted }(g)\end{array}$ & $\begin{array}{l}\text { Total dry weight } \\
\text { excreted }(g)\end{array}$ & $\begin{array}{l}\text { Total glucose } \\
\text { and small } \\
\text { oligosaccharide }(\mathrm{mg})\end{array}$ & $\begin{array}{l}\text { Concentration of } \\
\text { glucose and small } \\
\text { oligosaccharide } \\
\text { (mg/g wet weight) }\end{array}$ \\
\hline \multicolumn{6}{|c|}{ Crohn's disease } \\
\hline \multirow[t]{2}{*}{1} & A & $108 \cdot 1$ & $11 \cdot 1$ & $71 \cdot 5$ & 0.66 \\
\hline & B & $165 \cdot 1$ & $13 \cdot 6$ & $120 \cdot 4$ & 0.73 \\
\hline \multirow[t]{2}{*}{2} & A & $271 \cdot 2$ & $22 \cdot 6$ & $85 \cdot 5$ & $0 \cdot 32$ \\
\hline & B & 376.8 & $34 \cdot 3$ & $169 \cdot 1$ & 0.50 \\
\hline \multirow[t]{2}{*}{3} & A & $76 \cdot 3$ & $9 \cdot 3$ & $91 \cdot 6$ & $1 \cdot 20$ \\
\hline & B & $138 \cdot 2$ & $19 \cdot 8$ & 222.6 & 1.61 \\
\hline \multirow[t]{2}{*}{4} & A & 121.9 & $11 \cdot 7$ & $93 \cdot 1$ & 0.76 \\
\hline & B & 207.9 & $19 \cdot 3$ & $221 \cdot 0$ & 1.06 \\
\hline \multirow[t]{2}{*}{5} & $\mathbf{A}$ & $104 \cdot 3$ & $8 \cdot 6$ & $42 \cdot 8$ & $0 \cdot 41$ \\
\hline & B & $354 \cdot 2$ & $32 \cdot 2$ & 147.9 & 0.42 \\
\hline \multicolumn{6}{|c|}{ Ulcerative colitis } \\
\hline \multirow[t]{2}{*}{6} & A & $86 \cdot 5$ & $8 \cdot 0$ & $37 \cdot 5$ & 0.43 \\
\hline & B & $130 \cdot 7$ & $18 \cdot 2$ & $118 \cdot 0$ & 0.90 \\
\hline \multirow[t]{2}{*}{7} & A & 142.0 & $11 \cdot 8$ & $108 \cdot 2$ & 0.76 \\
\hline & B & $183 \cdot 1$ & $18 \cdot 1$ & $210 \cdot 5$ & $1 \cdot 15$ \\
\hline \multirow[t]{2}{*}{8} & A & 234.6 & $21 \cdot 2$ & $78 \cdot 2$ & 0.33 \\
\hline & B & $305 \cdot 1$ & $28 \cdot 2$ & 196.4 & 0.64 \\
\hline \multirow[t]{2}{*}{9} & A & $179 \cdot 8$ & $18 \cdot 0$ & $95 \cdot 1$ & 0.53 \\
\hline & B & $298 \cdot 7$ & $25 \cdot 1$ & 135.8 & 0.46 \\
\hline \multirow[t]{2}{*}{10} & $\mathbf{A}$ & $294 \cdot 0$ & $26 \cdot 4$ & $117 \cdot 8$ & 0.40 \\
\hline & B & $219 \cdot 4$ & $26 \cdot 8$ & $148 \cdot 4$ & 0.68 \\
\hline \multirow[t]{2}{*}{ Mean $\pm S D$} & $\mathbf{A}$ & $161 \cdot 9 \pm 79 \cdot 0$ & $14.9 \pm 6 \cdot 6$ & $82 \cdot 1 \pm 25 \cdot 8$ & $0 \cdot 58 \pm 0 \cdot 27$ \\
\hline & B & $237 \cdot 9 \pm 89 \cdot 5$ & $23 \cdot 6 \pm 6 \cdot 8$ & $169 \cdot 0 \pm 40 \cdot 8$ & $0.82 \pm 0.37$ \\
\hline$P_{A v s} B$ & & $t=-2.98(p<0.02)$ & $\mathrm{t}=-4.37(\mathrm{p}<0.01)$ & $\mathrm{t}=-7.53(\mathrm{p}<0.001)$ & $\mathrm{t}=-4.07(\mathrm{p}<0.01)$ \\
\hline
\end{tabular}

the subjects was higher on diet B than on $\operatorname{diet} A$. In all samples the amount of free glucose was lower than the amount of oligosaccharide, usually by a factor of 3.

\section{BREATH HYDROGEN}

No hydrogen was detected in the breath of any of the nine patients studied on either diet.

\section{BACTERIOLOGY (Table 5)}

The maximum amount of effluent was produced in the $0-1$ hour and the 3-6 hour periods; the results were analysed at $0-1$ hour, 3-4 and 5-6 hours, after the test breakfast. The total fiora, as well as the total obligate anaerobes, and total facultative anaerobes, tended to be higher on diet B than on $\operatorname{diet} \mathrm{A}$, as were all of the individual groups of organisms listed (Table 5). All samples contained bacteria and the predominant organisms were facultative streptococci. Most contained anaerobes but bacteroides and bifidobacteria, which between them account for $99 \%$ of the normal faecal flora, were often not present at all in these ileostomy samples. Bacteroides spp were isolated from only three patients and only regularly from two patients (one
Table 5 Bacterial counts (expressed as $\log _{10} / g$ wet weight of terminal ileum contents obtained by intubation) at various points after the two test breakfasts

\begin{tabular}{|c|c|c|c|c|}
\hline $\begin{array}{l}\text { Bacterial } \\
\text { group }\end{array}$ & Diet & $0-1 \mathrm{hr}$ & $3-4 h r$ & $5-6 h r$ \\
\hline Total flora & $\begin{array}{l}\mathbf{A} \\
\mathbf{B}\end{array}$ & $\begin{array}{l}5 \cdot 45 \pm 1.689 \\
6 \cdot 85 \pm 1 \cdot 15\end{array}$ & $\begin{array}{l}6 \cdot 53 \pm 1 \cdot 12 \\
7 \cdot 24 \pm 1 \cdot 12 \dagger\end{array}$ & $\begin{array}{l}6 \cdot 79 \pm 1 \cdot 15 \\
7 \cdot 48 \pm 1.40 \dagger\end{array}$ \\
\hline $\begin{array}{l}\text { Total faculta- } \\
\text { tive anaerobes }\end{array}$ & $\begin{array}{l}\mathbf{A} \\
\mathbf{B}\end{array}$ & $\begin{array}{l}5 \cdot 34 \pm 1.61 \\
6 \cdot 82 \pm 1 \cdot 14\end{array}$ & $\begin{array}{l}6 \cdot 48 \pm 1 \cdot 18 \\
7 \cdot 20 \pm 1 \cdot 0 \dagger\end{array}$ & $\begin{array}{l}6 \cdot 75 \pm 1 \cdot 14 \\
7 \cdot 30 \pm 1 \cdot 36\end{array}$ \\
\hline Streptococci & $\begin{array}{l}\mathbf{A} \\
\mathbf{B}\end{array}$ & $\begin{array}{l}5 \cdot 14 \pm 1.70 \\
6 \cdot 45 \pm 0.91\end{array}$ & $\begin{array}{l}6 \cdot 28 \pm 1 \cdot 10 \\
7 \cdot 04 \pm 1 \cdot 03 \dagger\end{array}$ & $\begin{array}{l}6 \cdot 52 \pm 1 \cdot 01 \\
7 \cdot 32 \pm 1 \cdot 45^{*}\end{array}$ \\
\hline Enterococci & $\begin{array}{l}\mathbf{A} \\
\mathbf{B}\end{array}$ & $\begin{array}{l}4 \cdot 72 \pm 1.65 \\
5 \cdot 76 \pm 1 \cdot 23\end{array}$ & $\begin{array}{l}5 \cdot 40 \pm 1 \cdot 28 \\
6 \cdot 24 \pm 1 \cdot 05 \ddagger\end{array}$ & $\begin{array}{l}6 \cdot 12 \pm 1 \cdot 24 \\
6 \cdot 77 \pm 1 \cdot 44^{*}\end{array}$ \\
\hline Enterobacteria & $\begin{array}{l}\mathbf{A} \\
\mathbf{B}\end{array}$ & $\begin{array}{l}3 \cdot 75 \pm 1.55 \\
5 \cdot 30 \pm 1 \cdot 84\end{array}$ & $\begin{array}{l}3 \cdot 94 \pm 1 \cdot 58 \\
4 \cdot 80 \pm 2 \cdot 12\end{array}$ & $\begin{array}{l}4 \cdot 72 \pm 1 \cdot 59 \\
5 \cdot 41 \pm 1 \cdot 91\end{array}$ \\
\hline Lactobacilli & $\begin{array}{l}\mathbf{A} \\
\mathbf{B}\end{array}$ & $\begin{array}{l}3 \cdot 13 \pm 1.22 \\
4 \cdot 02 \pm 1 \cdot 19 \ddagger\end{array}$ & $\begin{array}{l}3 \cdot 51 \pm 1 \cdot 87 \\
4 \cdot 33 \pm 1 \cdot 58\end{array}$ & $\begin{array}{l}3 \cdot 58 \pm 1 \cdot 19 \\
4 \cdot 62 \pm 1 \cdot 39\end{array}$ \\
\hline $\begin{array}{c}\text { Total obligate } \\
\text { anaerobes }\end{array}$ & $\begin{array}{l}\mathbf{A} \\
\mathbf{B}\end{array}$ & $\begin{array}{l}4 \cdot 18 \pm 1.91 \\
5 \cdot 08 \pm 1 \cdot 44\end{array}$ & $\begin{array}{l}5 \cdot 04 \pm 1 \cdot 15 \\
5 \cdot 42 \pm 1 \cdot 54\end{array}$ & $\begin{array}{l}5 \cdot 01 \pm 1 \cdot 55 \\
5 \cdot 42 \pm 2 \cdot 11\end{array}$ \\
\hline Bacteroides & $\begin{array}{l}\mathbf{A} \\
\mathbf{B}\end{array}$ & $\begin{array}{l}2 \cdot 72 \pm 0.88 \\
3 \cdot 65 \pm 1 \cdot 39 \dagger\end{array}$ & $\begin{array}{l}3 \cdot 22 \pm 1 \cdot 21 \\
3 \cdot 53 \pm 1 \cdot 70\end{array}$ & $\begin{array}{l}3 \cdot 16 \pm 1 \cdot 05 \\
3 \cdot 77 \pm 1 \cdot 76\end{array}$ \\
\hline Veillonella & $\begin{array}{l}\mathbf{A} \\
\mathbf{B}\end{array}$ & $\begin{array}{l}3 \cdot 08 \pm 0.83 \\
4 \cdot 60 \pm 1 \cdot 75^{*}\end{array}$ & $\begin{array}{l}4 \cdot 51 \pm 1 \cdot 23 \\
4 \cdot 81 \pm 1 \cdot 59\end{array}$ & $\begin{array}{l}4 \cdot 23 \pm 1 \cdot 35 \\
5 \cdot 11 \pm 1 \cdot 98\end{array}$ \\
\hline Clostridium spp & $\begin{array}{l}\mathbf{A} \\
\mathbf{B}\end{array}$ & $\begin{array}{l}3 \cdot 65 \pm 2.03 \\
4 \cdot 23 \pm 1 \cdot 60\end{array}$ & $\begin{array}{l}3 \cdot 94 \pm 1 \cdot 61 \\
3 \cdot 88 \pm 1 \cdot 47\end{array}$ & $\begin{array}{l}3 \cdot 86 \pm 1 \cdot 52 \\
4 \cdot 40 \pm 1 \cdot 91\end{array}$ \\
\hline
\end{tabular}

I Mean \pm standard deviation. $\quad \mathrm{A}<\mathrm{B}$ paired $t$ test.

* $\mathrm{p}<0.05 ; \uparrow \mathrm{p}<0.02 ; \ddagger \mathrm{p}<0.01$. 
Crohn's disease and one ulcerative colitis) while bifidobacteria were present in most of the samples from two patients (both ulcerative colitis) and occasionally from samples from three other patients. Veillonella spp was the dominant anaerobe in nine of the 10 patients. No differences were observed in the ileal microflora of patients with Crohn's disease compared with those with ulcerative colitis.

\section{Discussion}

As the incidence of Crohn's disease has increased greatly in Europe during the last 50 years, it is reasonable to look for an environmental factor. A change in the composition of the diet could be relevant and two characteristics of the present Western diet are its high content of sucrose and relatively low content of fibre. A series of dietary surveys have all shown that patients with Crohn's disease tend to eat more sucrose than healthy control subjects or patients with ulcerative colitis. ${ }^{1-9}$ A retrospective study has suggested that a diet low in refined, and high in unrefined, carbohydrate benefited patients with Crohn's disease. ${ }^{23}$ It could be that a large intake of sucrose affects the bacterial flora of the distal ileum and colon, and thus, in some way predisposes to, or perpetuates, the inflammation of Crohn's disease. The experiment reported here was designed to study the effect of altering dietary sucrose and fibre on the bacterial flora of the distal ileum under the artificial, but experimentally convenient, conditions afforded by an ileostomy.

Equal numbers of subjects treated by colectomy for Crohn's disease or ulcerative colitis were studied in case the effect of diet proved to be different in the two groups, though in the event the results were indistinguishable. Patients took each diet for a total of 15 days in the expectation that this equilibration period would allow any change in gut flora associated with the diet to become established. The test meals taken under supervision on the 15th day were not only characteristic of food taken in the previous two weeks, but also carefully designed to alter only sucrose and fibre, without alteration in protein, fat or total calories. A controlled comparison of the bacterial flora and the ileostomy effluent with each of the diets was thus possible.

The luminal flora of the distal ileum was sampled through a tube passed into the ileostomy and the specimen was immediately frozen in transport medium without exposure to air. Gorbach and his colleagues observed that samples obtained from the distal ileum by peroral intubation contained 80 times fewer organisms than ileostomy effluent and that the ratio of aerobes to anaerobes was approximately equal in both. ${ }^{24}$ Their figure for total bacterial count, approximately $10^{6}$ per gram, corresponds closely with the results shown in Table 5; our finding of fewer obligate anaerobes $\left(10^{5}\right.$ compared with $\left.10^{6}\right)$ and more facultative anaerobes $\left(10^{6}\right.$ compared with $10^{5}$ ) probably reflects differences in technique. Drasar $e t a^{25}$ studied the bacterial flora of the lower small intestine by peroral intubation in six normal subjects. They found that the numbers of bacteria isolated increased as the terminal ileum was approached where samples were qualitatively similar to faeces. In one subject studied at intervals after a meal, the flora decreased for up to $3 \frac{1}{2}$ hours after food. Such a decrease was not observed in the present study (Table 5). The results of Finegold $e t$ $a l^{26}$ who quantified the bacterial flora of ileostomy effluent, correspond with the findings of Gorbach $e t$ $a l^{24}$ in showing a higher total count than that obtained by intubation. In their results aerobes predominated over anaerobes in every patient, the converse of the normal faecal populations.

Our results show an approximately 10 -fold increase of total bacteria per gram of effluent when patients took a low sucrose high unrefined carbohydrate diet as compared with the high sucrose, low fibre regime. All types of bacteria increased by approximately the same factor and there was no obvious alteration in the relative proportions of different types of organism. Facultative anaerobes predominated over obligate anaerobes by a factor between 10- and 100-fold with both diets. Bacteroides and bifidobacteria, the dominant organisms in faeces, were absent in many specimens obtained from the distal ileum, and were not isolated at all from five patients. This observation corresponds with the results of Finegold et $a l^{26}$ who were unable to isolate Bacteroides fragilis from any ileostomy ieffluent, indeed one of their seven subjects had no anaerobes in the effluent, but they did find the organism in every specimen of faeces.

To our surprise, both the concentration and total amount of glucose and oligosaccharides, though small, were greatest with the low sucrose high unrefined carbohydrate diet. It seems likely that sucrose was absorbed in the upper intestine and that the small carbohydrate molecules found in the ileostomy effluent were derived from breakdown of fibre. The increased bacterial flora could possibly be because of the presence of this metabolic substrate. The total and dry weights of the ileostomy effluent were about $50 \%$ greater with the high than with the low unrefined carbohydrate diet. This fact may explain why ileostomists tend to restrict their fibre intake slightly as compared with control subjects. ${ }^{27}$

This experiment has not supported the postulate that alterations in the sucrose and unrefined carbohydrate contents of the diet markedly affects the 
balance of the bacterial flora in the terminal ileum although it affects the total concentration of organisms. The results add confirmation to those already obtained showing that the bacterial flora of faeces is a poor indicator of the flora in the distal ileum or right colon. ${ }^{24-26}$ It is thus difficult to assess the significance of the observation that the anaerobic flora may be increased in the faeces of patients with terminal ileal Crohn's disease. ${ }^{28}$ The findings are in accord with those of Stephen and Cummings $^{29-31}$ that a high fibre diet increases the bacterial content of stool; our results show that such a diet is also associated with greater bacterial numbers in the lumen of the distal ileum.

Dr Berghouse is grateful to the Sir Halley Stewart Trust for financial support. Dr Hori was a Sir Thomas Hunt Memorial Fellow of the British Digestive Foundation. We also thank the Cancer Research Campaign and Public Health Laboratory Service Board for support in this study.

\section{References}

1 Martini GA, Brandes JW. Increased consumption of refined carbohydrate in patients with Crohn's disease. Klin Wochenschr 1976; 54: 367-71.

2 Miller B, Fervers F, Rohbeck R, Strohmeyer G. Zuckerhonsom bei patienten mit morbis Crohn. Vehr Dtsch Ges Inn Med 1976; 82: 922-4.

3 Mayberry JF, Rhodes J, Newcombe RG. Breakfast and dietary aspects of Crohn's disease. $\mathrm{Br}$ Med J 1978; 2: 1401.

4 Kasper H, Sommer H. Dietary fiber and nutrient intake in Crohn's disease. Am J Clin Nutr 1979; 32: 1898-1901.

5 Thornton JR, Emmett PM, Heaton KW. Diet and Crohn's disease: characteristics of the pre-illness diet. Br Med J 1979; 2: 762-4.

6 Mayberry JF, Rhodes J, Newcombe RG. Increased sugar consumption in Crohn's disease. Digestion 1980; 20: $323-6$.

7 Silkoff K, Hallak A, Yenena L et al. Consumption of refined carbohydrate by patients with Crohn's disease in Tel-Aviv-Yafo. Postgrad Med J 1980; 56: 842-6.

8 Mayberry JF, Rhodes J, Allan R et al. Diet in Crohn's disease: Two studies of current and previous habits in newly diagnosed patients. Dig Dis Sci 1981; 26: 444-8.

9 Jarnerot G, Jarnmark I, Nillson K. Sugar Consumption in Crohn's Disease (CD), Ulcerative colitis (UC) and irritable bowel syndrome (IBS). [Abstract 1401] Scand J Gastroenterol 1982; 17: suppl 78: 352.

10 Paul AA, Southgate DAT. The composition of foods. London: HMSO, 1978.

11 Crowther JS. Transport and storage of faeces for bacteriological examination. J Appl Bacteriol 1971; 34:
477-83.

12 Drasar B. The isolation and identification of nonsporing anaerobes. In: Phillips I, Sussman M, eds. Infection with non-sporing anaerobic bacteria. Edinburgh: Churchill-Livingstone, 1974: 20-35.

13 Miles AA, Misra SS. The estimation of the bactericidal power of the blood. J Hyg (Camb) 1938; 38: 732-48.

14 Borriello SP, Hudson MJ, Hill MJ. Investigation of the gastrointestinal bacterial flora. Clin Gastroenterol 1978; 7: 329-49.

15 Rogosa M. A selective medium for the isolation and enumeration of the veillonella from the oral cavity. $J$ Bacteriol 1956; 72: 533-6.

16 Sutter VL, Sugihara PT, Finegold SM. Rifampicinblood-agar as a selective medium for the isolation of certain anaerobic bacteria. Appl Microbiol 1971; 22: $777-80$.

17 Donnelly LS, Hartman PA. Gentamicin based medium for the isolation of group D streptococci and application of the medium to water analysis. Appl Environ Microbiol 1978; 35: 576-81.

18 Koransky JR, Allen SD, Dowell VR Jr. Use of ethanol for selective isolation of sporeforming microorganisms. Appl Environ Microbiol 1978; 35: 762-5.

19 Cowan ST. Cowan and Steel's manual for the identification of medical bacteria. London: Cambridge University Press, 1974.

20 Ito Y, Yodoshi M, Tanaka J, Iwaida M. Comparison of two methods and improvements for colorimetric determination of nitrate in cod roe. J Food Protection 1979; 42: $715-8$.

21 Harper HA. Review of physiological chemistry. 14th Edition, Canada: Lange Medical Publications, 1973.

22 Metz GL, Gassull MA, Leeds AR, Blendis LM, Jenkins DJA. A simple method for measuring breath hydrogen in carbohydrate malabsorption by endexpiratory sampling. Clin Sci Molec Med 1976; 50: 237-40.

23 Heaton KW, Thornton JR, Emmett PM. Treatment of Crohn's disease with an unrefined-carbohydrate, fibrerich diet. Br Med J 1979; 2: 764-6.

24 Gorbach SL, Nahas L, Weinstein L, Levitan R, Patterson JF. Studies of intestinal microflora IV. The microflora of ileostomy effluent: a unique microbial ecology. Gastroenterology 1967; 53: 874-80.

25 Drasar BS, Shiner M, McLeod GM. Studies on the intestinal flora I. The bacterial flora of the gastrointestinal tract in healthy and achlorhydric persons. Gastroenterology 1969; 56: 71-9.

26 Finegold SM, Sutter VL, Boyle JD, Shimada K. The normal flora of ileostomy and transverse colostomy effluents. J Infect Dis 1970; 122: 376-81.

27 Bingham S, Cummings JH, McNeil NI. Diet and health of people with an ileostomy I. Dietary assessment. Br J Nutr 1982; 47: 399-406.

28 Wensink F, Custers-van Lieshout LMC, PoppelaarKusterman PAJ, Shroder AM. The faecal flora of patients with Crohn's disease. J Hyg (Camb) 1981; 87: $1-12$.

29 Stephen AM, Cummings JH. The influence of dietary fibre on faecal nitrogen excretion in man. [Abstract] Proc Nutr Soc 1979; 38: 141A. 
30 Stephen AM, Cummings JH. The microbial contribution to human faecal mass. J Med Microbiol 1980; 13: 45-56.
31 Stephen AM, Cummings JH. Mechanism of action of dietary fibre in the human colon. Nature 1980; 284: 283-4.

\section{Forthcoming Scientific Meetings of the British Society of Gastroenterology}

Brighton 20-22 March 1985

Newcastle-upon-Tyne 18-20 September 1985

Lancaster 9-11 April 1986

Cardiff 24-26 September 1986

London 15-18 September 1987

For details of registration please contact: The Administrative Secretary, British Society of Gastroenterology, Rayne Institute, 5 University Street, London, WC1E 66JJ. Tel: (44: country code) 01-387-3534. 